\title{
Observations on the Development of Human Dignity and Personality in German Constitutional Law: An Overview
}

\author{
Edward J. Eberle
}

Published online: 9 January 2013

(C) The Author(s) 2013. This article is published with open access at Springerlink.com

\begin{abstract}
This paper provides an overview of the development of the constitutional value of human dignity under German constitutional law. First, it provides a background to the German constitutional order then it places the constitutional value of dignity within the framework of the constitutional court's jurisprudence on personality rights. It then progresses to an examination of specific cases that have developed personality rights and the importance of the constitutional court's interpretation of personality and dignity in the personal and outer spheres within the framework of the German legal order. The article concludes with some observations and comparisons between German and American law in this area.
\end{abstract}

Keywords German constitutional law · Dignity · Personality rights · Inner and outer - American law

\section{Introduction}

The quest for human dignity in modern society is a noble but elusive goal. Difficult to define, ${ }^{1}$ difficult to realize, personally or socially, dignity nevertheless remains a defining trait of human character, and a preeminent ideal of western society.

\footnotetext{
1 In western thought, the most definitive elaboration of the concept of human dignity is in the work of Immanuel Kant (1959). Recently, there has been a renaissance in the influence of Kantian thought, as a counterweight to utilitarianism. This is most pronounced in the work of Rawls $(1971,1993)$. There are other conceptions of dignity too. Dworkin (1977, 1986), Nozick (1974).
}

All rights reserved. Excepts of this article are taken from my article on Human Dignity, Privacy, and Personality in German and American Constitutional Law, 1997 Utah L. Rev. 963.

E. J. Eberle ( $\square)$

Roger Williams University School of Law, Bristol, RI, USA

e-mail: eeberle@rwu.edu 
From the perspective of an individual, dignity might be thought of as the ability to pursue one's rights, claims or interests in daily life so that one can attain full realization of one's talents, ambitions or abilities, as one would like. That is one path to satisfaction, social recognition and stature, certainly attributes of dignity. This might be thought of as self-realization, although that is not the only conception of dignity. What matters here is that each person should be free to develop his own personality to the fullest subject only to restrictions arising from others' pursuit of the same. ${ }^{2}$

Of course, there must be some limit to individual freedom if society is to function in a reasonably orderly manner. Thus, from the standpoint of society, individual aspiration must be measured against the demand for order, peace and social harmony. This balance between the aspiration of individual freedom and the demands of organized society has been a central quest of modern constitutional law. ${ }^{3}$

Today this balance is harder than ever to achieve. Social demands have escalated, placing elevated pressures on the integrity of human personhood. The rise of the administrative state, for example, has led to omnipresent government and its potential to suffocate personal freedom. ${ }^{4}$ Technology now develops so rapidly and pervasively that it risks overwhelming individuality. For example, computers can gather, store and transmit information so capably that they can access and, even, mimic human functions. ${ }^{5}$ Gene technology, artificial insemination and the ability to prolong and, indeed, end life pose troubling existential questions. How are we coping in this world, in isolation or in comparison to others?

This article takes up these themes by exploring the concept of human dignity, as reflected in the German legal order. Germany is a good choice for this evacuation because of its European intellectual and cultural influences; a highly developed, advanced industrial society, coping with change and technological revolution; and strives to meet the aspiration of individual freedom within a stable social construct.

Human dignity is, of course, an elusive concept to define. For our purposes, we will concentrate on the content given the term by the German constitutional law. In particular, we will explore how persons are free to develop their own personalities. A person might choose, for example, to be let alone as master of his/her realm. Or, one might engage vigorously in the affairs of the day. In Germany, these matters are covered in the right to the free unfolding of personality. It makes sense to focus on the constitutional law of a country because recording in a constitution a culture's highest values is a defining attribute of western society. Certainly this is the case with Germany. The Basic Law, as interpreted by the Constitutional Court, guides and organizes society. By exploring this concept of human dignity in the constitutional order, insight can be derived as to the quality of the human condition, the reach of individual freedom, and the make up of the social order. The particular traits,

\footnotetext{
2 This is fundamentally a Kantian thought that each moral agent should develop their talents to the maximum extent compatible with the freedom of others. For Kant, the concepts of freedom, development of moral personality, reverence of the moral law and treating people as the final end are interlinked.

3 See, e.g., Poe v. Ullman, 367 U.S. 497, 542 (1961).

4 Eberle (1999).

5 See, e.g., Schwartz (1989).
} 
activities or essences sought to be realized by each country reveals something important about human personality as it relates to society. Likewise, the limitations on freedom articulated are instructive of the social structure sought to be created. In short, the balance struck between individual freedom and the social order illuminates the legal culture.

To accomplish these goals, some grounding in German constitutional law is first necessary, particularly its protection of human dignity and personality. This is the subject of the first part. The second part provides an overview of human dignity as developed in German personality rights. The third part details freedom of action, is outward in focus, including protection of activities like freedom to travel. German law also guarantees a personal sphere that is inward in orientation which is the subject of the fourth part. This entails a number of strands, such as informational self-determination. The final part makes some observations on Germany's view of human dignity and the strength of its constitutional vision.

\section{The German Constitutional Order and Its Protection of Human Dignity and Personality}

\section{The German Constitutional Order}

The adoption of the Basic Law in 1949, following the debacle of World War II, signaled a new constitutional order in Germany. Seeking distance from the horrors of Nazism, the Basic Law makes a sharp break from this immediate past, instead drawing deeply upon German tradition to found the legal order on moral and rational idealism, particularly that of Kant. ${ }^{6}$ Thus, the Basic Law is a value-oriented constitution that obligates the state to realize a set of objectively ordered principles, rooted in justice and equality that are designed to restore the centrality of humanity to the social order, and thereby secure a stable democratic society on this basis. These values are not to be sacrificed for the exigencies of the day, as had been the case during the Nazi time. ${ }^{7}$ The Rechtsstaat principle, for example, obligates society to adhere to a rule of law, requiring that legal measures have a legal basis and discernible content, provide fair notice and be necessary and proportional to the ends they seek to accomplish (proportionality Principle). The principle of the Social State (Sozialstaatsprinzip) obligates the state to take necessary social-welfare measures so that all citizens will have a dignified existence. ${ }^{8}$ The concept of a "militant democracy" (streitbare Demokratie) obligates the state to resist any threats to the basic democratic order, thereby assuring the flourishing of democracy. ${ }^{9}$

Crucial also to the German social order is commitment to human rights. Many fundamental values are enumerated in a catalogue of basic rights, including

\footnotetext{
${ }^{6}$ von Muench (1981) [hereinafter "Muench Commentary]; Kommers (1989); Badura (1964).

7 Fletcher (1984).

8 See Basic Law article 20(1). For elaboration of the concept of the Social State, See Kommers (1989). For the intellectual origins of the Social State.

9 See, e.g., Klass Case, 30 BVerfGE 1, 19-20 (1970).
} 
protections of free conscience, faith and creed, free expression, equality and occupational freedom. The Basic Law is far more specific and comprehensive in its listing of basic freedoms, enumerating at least twenty specific individual liberties, as compared to the relatively sparse enumeration of liberties in the American Constitution. $^{10}$

There are differences in the countries' conception of basic rights. Fundamental to the German constitutional scheme is the principle of objective and subjective rights, or positive and negative liberties. The objective dimension of rights obligates the government to create the proper conditions so that rights might be realized. ${ }^{11}$ This bestows duties on the state, calling for state activism along these lines. For example, the concept of human dignity protected in Article one obligates the state to provide a basic minimal existence for citizens. ${ }^{12}$ This objective dimension to basic rights is tied to the value-ordered nature of the German constitutional scheme, obligating the government to realize in society the set of objective values embodied in the Basic Law. "This value-system, which centers upon human dignity and the free unfolding of the human personality within the social community, must be looked upon as a fundamental constitutional decision affecting all areas of law, public and private."13 By interpreting basic rights as establishing an "objective" ordering of values, centered around human dignity, the Constitutional Court transformed those values into principles so important that they must exist "objectively"-as an independent force, separate from their specific manifestation in a concrete legal relationship. So conceived, objective rights form part of the legal order-the ordre public, thereby becoming part of the governing principles of German society. ${ }^{14}$ In this way, the Basic Law acts as a blueprint for society, setting forth the values to be realized, requiring a close fit between its text and society.

The second aspect of German basic rights is their subjective or negative dimension. This means that rights play a defensive role, delimiting a sphere of personal liberty beyond governmental control. In German law, this concept of rights is referred to as "subjective," denoting a set of rights exercisable by individuals. The essential character of this subjective dimension corresponds to the American conception of fundamental constitutional rights. In contrast to the American constitution, the German Basic Law also sets forth certain duties incumbent upon citizens or government to perform. For example, article 6(2) provides that "(T)he care and upbringing of children shall be a natural right of and a duty primarily incumbent on the parents. The state shall watch over their endeavors in this respect." 15 Moreover, the objective value order, as worked out by the Court,

\footnotetext{
10 These differences should be expected in charters drafted in 1949 and 1791 (Bill of Rights).

11 Quint (1989).

12 This provides the foundation for the social welfare principle, anchored in article 20(1), that distinguishes Germany.

13 Lüth, 7 BVerfGE 198, 205 (1958).

14 Eberle (1999). They might even be viewed as "permanent ends of the state," not "changeable" even by constitutional amendment. Quint (1989), noting Art. 79(3) GG.).

15 In actuality, duties are only sparingly spelled out in the Basic Law, in contrast to the 1918 Weimar Constitution, which elaborated a set of duties. See Eberle (1999). See Pieroth and Schlink (1994).
} 
calibrates the relationships between rights, and among rights and duties. Thus, German citizens have both claims to subjective rights, which they may exercise, and objective rights, which they can call on government to perform, and must, additionally, assume duties as to how to act on such rights. We can thus see that the contrast between the text and nature of the two constitutions is striking. The German Basic Law is value-oriented and sets forth both rights and duties, whereas the United States Constitution attempts to be value-neutral pursuant to a scheme of negative liberties, specifically enumerating rights government may not infringe, but not stating comparable duties citizens must assume or values government must realize.

Constitutional interpretative techniques in Germany place a premium on the text of the Basic Law and it applicability to social and economic conditions. Beyond textual and structural exegesis, German interpreters would also employ historical and teleological analysis, before integrating the whole through techniques of harmonization (praktische Konkordanz) and integration. ${ }^{16}$ The Constitutional Court employs a variety of reasoning techniques, including arguments based on text, structure, history and natural law. ${ }^{17}$

In Germany, the Constitutional Court treats history as an auxiliary source of interpretation. While the Court is free to consult Framers' intent, such history generally lends support to a result reached through other interpretative methods, such as the textual, structural or teleological analysis noted above. Framers' intent is not an independent source of authority. ${ }^{18}$ Instead, the Court mainly interprets constitutional text in relationship to the conditions of modern society. This is perhaps most pronounced in relation to the article one concept of human dignity, where the Court has stated: "any decision defining human dignity in concrete terms must be based on our present understanding of it and not on any claim to a conception of timeless validity."19

\section{Human Dignity in Germany}

Human dignity is the central value of the Basic Law. This determination reflects the conscious intention to elevate modern Germany beyond the inhumanity of Nazism, signaling a new constitutional order. Article 1(1) therefore states "The dignity of man shall be inviolable." The second paragraph of article one reinforces the centrality of human rights to the concept of human dignity: "The German people therefore acknowledge inviolable and inalienable human rights as the basis of every community, of peace and of justice in the world." 20

\footnotetext{
16 See Brugger (1994). See also Kommers (1989).

17 Kommers (1989).

18 Brugger (1994), Kommers (1989). Note, for example, the Constitutional Court: "the original history of a particular provision of the Basic Law has no decisive importance" in constitutional interpretation. Homosexuality Case, 6 BVerfGE 389, 431 (1957), translated in Kommers (1989).

19 Life Imprisonment Case, 45 BVerfGE 187, 229 (1977), translated in Currie (1994).

${ }^{20}$ Kommers (1989). For elaboration of the Kantian roots of the Basic Law, particularly in Articles one and two, See Ewald (1995).
} 
A core aspect of human dignity is the guarantee of human rights. Indeed, the specific enumeration of basic rights in the Basic Law are themselves tangible manifestations of human dignity. This catalogue of basic rights is systematically ordered, making up a central aspect of the objectively determined set of values that govern German society. In this way, dignity and basic rights have a mutually nourishing effect on one another. ${ }^{21}$ But human dignity means more than the specific catalogue of basic rights. Dignity is not merely a focus on individuality. As the central value of the constitution, it infuses throughout the whole constitutional order, obligating the state both to protect and realize it. This includes a communitarian dimension; by requiring respect for others' claims to dignity, vindication for the human dignity of all is better assured, and a community of mutual cooperation and solidarity is fostered.

The concept of human dignity in the Basic Law reflects the influence of three main schools of thought, although it was not intended to be strictly associated with any one of them. The three influences are Christian natural law, Kantian moral philosophy and more secular theories of personal autonomy and self-determination. $^{22}$ In the dignitarian jurisprudence of the Constitutional Court, however, the Court has mainly followed Kant's theory of moral autonomy. This is evident, for example, in the leading Life Imprisonment Case, where the Court attempted to capture the essence of human dignity:

It is contrary to human dignity to make the individual the mere tool (blosses Objekt) of the state. The principle that "each person must always be an end in himself" applies unreservedly to all areas of the law; the intrinsic dignity of the person consists in acknowledging him as an independent personality. ${ }^{23}$

Still, human dignity is essentially an abstract, normative concept, albeit with a philosophical framework, and the Framers sought, and the Court has striven, to keep the term an open one, preferring that it take on concrete meaning through case-bycase determination. Thus, the main definition of dignity is the meaning given it by the Court in its jurisprudence.

\section{Human Personhood and the Polity}

The dignitarian jurisprudence of the Constitutional Court is replete with references to the nature of humankind and society. ${ }^{24}$ The Court has frequently characterized man as a "spiritual-moral being," reflecting the Christian-natural law influence. The Life Imprisonment Case is again a good statement of this:

\footnotetext{
21 Kommers (1989).

${ }^{22}$ Under Christian natural law theories, dignity is a gift of God and, therefore, an inalienable aspect of humanity. Under Kantian philosophy, dignity is an indispensable part of human nature. Under a more secular theory of self-realization, the decisive aspect of human dignity is self-realization of one's identity through exercise of one's talents and abilities. For elaboration of these theories, and their influence on human dignity, See Pieroth and Schlink (1994).

2345 BVerfGE 187, 228 (1977), translated in Currie (1994).

${ }^{24}$ Kommers (1989) ("The Constitutional Court's 'dignitarian' jurisprudence contains numerous declarations about the nature of the human person and the polity").
} 
The constitutional principles of the Basic Law embrace the respect and protection of human dignity. The free human person and his dignity are the highest values of the constitutional order. The state in all of its forms is obliged to respect and defend it. This is based on the conception of man as a spiritual-moral being endowed with the freedom to determine and develop himself. $^{25}$

A strongly Kantian view likewise invests the concept of personhood with rationality and self-determination, but also with duties and moral bounds. These strands of thought converge to form an integrated, whole person. As envisioned in German law, human beings are spiritual-moral beings who are to act freely, but their actions are to be bound by a sense of moral duty. Actions, in other words, are to be guided by a sense of social need, personal responsibility and human solidarity. ${ }^{26}$

There is a strong linkage of the concept of personhood to the social community. The seminal case on artistic freedom, Mephisto, captured this thought well: "the human person (is) an autonomous being developing freely within the social community." 27 The human is not to be "an isolated and self-regarding individual," 28 as she so often seems to be in the American social scheme. Rather, the human is to be "related to and bound by the community." ${ }^{29}$ The Investment Aid Case first advanced the concept of the human as a community-bound person:

The image of man in the Basic Law is not that of an isolated, sovereign individual; rather, the Basic Law has decided in favor of a relationship between individual and community in the sense of a person's dependence on and commitment to the community, without infringing upon a person's individual value. $^{30}$

Once again, these statements bear the clear imprint of Kantian moral philosophy. Thus, the community envisioned by the Basic Law is one where individuality and human dignity are to be guaranteed and nourished, but with a sense of social solidarity and responsibility. Rather than a collection of atomistic individuals, people are connected to one another. Thus, individual self-determination is offset by concepts of "participation, communication and civility." ${ }^{31}$ In short, at the root of the German social vision is the Kantian proposition that humans are to be treated always as ends in themselves, and never as means, and that this is to be done within a moral social construct, that both empowers and guides people. The Life Imprisonment Case, again, gives good voice to these thoughts:

\footnotetext{
2545 BVerfGE 187, 227 (1977), translated in Kommers (1989).

26 Kommers (1989); Ewald (1995).

2730 BVerfGE 173, 193 (1971), translated in Kommers (1989).

28 Life Imprisonment Case, 45 BVerfGE 187, 227 (1977), translated in Kommers (1989).

29 Ibid.

304 BVerfGE 7, 15-16 (1954), translated in Kommers (1989); Klass Case, 30 BVerfGE 1, 20 (1979); Conscientious Objector Case I, 12 BVerfGE 45, 51 (1960).

31 Kommers (1989).
} 
This freedom within the meaning of the Basic Law is not that of an isolated and self-regarding individual but rather (that) of a person related to and bound by the community. In the light of this community-boundlessness it cannot be "in principle unlimited." The individual must allow those limits on his freedom of action that the legislature deems necessary in the interest of the community's social life; yet the autonomy of the individual has to be protected. This means that (the state) must regard every individual within society with equal worth. It is contrary to human dignity to make persons the mere tools [blosses objekt] of the state. The principle that "each person must shape his own life" applies unreservedly to all areas of law;" the intrinsic dignity of each person depends on his status as an independent personality." 32 The German social vision unfolds within a more shared sense of community.

\section{The Concrete Meaning of Human Dignity}

Since human dignity is a capacious concept, it is difficult to determine precisely what it means outside the context of a factual setting. As the driving principle of the legal order, however, and as a root of Kantian thought, it possesses a certain fixed content. At a minimum, for example, it means that the social order must reflect recognition of the equality of humankind. This concept is anchored in article three of the Basic Law. Equality means at least that persons are entitled to "equal worth" 33 and that, accordingly, there can be no slavery or serfdom, racial or ethnic discrimination. ${ }^{34}$ Second, dignity means respect of physical identity and integrity, which is textually specified in article 2(2). This prohibits torture and corporal punishment and forbids imposing punishment without fault or levying disproportionate penalties. ${ }^{35}$ Third, dignity means respect of intellectual and spiritual identity and integrity. ${ }^{36}$ This is manifested most dramatically in the protection of personality rights, specified in article two and elaborated on in this article. Fourth, dignity means limitation of official power. This is particularly evident in the guarantee of proportionality, which circumscribes governmental means to legitimate ends and of procedural due process rights, which allow persons affected by official action to be heard and to be able to influence proceedings which concern them. ${ }^{37}$ Fifth, dignity means guarantee of individual and social existence. Tangibly, this is manifested in the article 2(2) right to life and in Germany's social welfare state, textually anchored in article $20(1) .^{38}$

\footnotetext{
3245 BVerfGE at 227-28, translated in Kommers (1989). For elaboration of this, See Maunz (1993) [hereinafter "Maunz Commentary"].

33 Life Imprisonment, 45 BVerfGE at 228.

34 Pieroth and Schlink (1994).

35 Ibid.

36 Ibid.

37 Ibid. Note Article 19(4): "Should any person's rights be violated by public authority, recourse to the court shall be open to him.").

38 See Pieroth and Schlink (1994).
} 
The main development of dignitarian jurisprudence has occurred in conjunction with the more concrete freedoms of article two. There are three specific freedoms in article two. The first of these is the right to free development of personality, phrased in article 2(1) as "Everyone shall have the right to the free development of his personality insofar as he does not violate the rights of others or offend against the constitutional order or against morality." 39

The second of the important article two freedoms is "the right to life and to physical integrity." 40 The right to life clause is the source for the Constitutional Court's conclusion in the Abortion Cases $^{41}$ that the state has a duty to protect life after conception, which resulted in strict limitation of abortion. Apart from abortion, the Constitutional Court has not invoked the clause to place wide-ranging duties to protect life on the state. While recognizing a duty to protect life, the Court has deferred to government's implementation of it. Accordingly, the Court has rejected the imposition of affirmative state duties in relation to the prevention of kidnapping or rescuing of its victims ${ }^{42}$ or the guarding against threats to the environment from army bases or nuclear plants. ${ }^{43}$

The "physical integrity" clause is mainly used as a source to guide criminal procedures, somewhat like our criminal due process jurisprudence. ${ }^{44}$ It has also been used to limit invasions of the body that would cause pain, harm, disfigurement or injury. For example, in the Spinal Tap Case, the Court invalidated a court-ordered sampling of a defendant's spinal column to test his involvement in a crime on the ground that this violated one's physical integrity. ${ }^{45}$ The Court has also invalidated use of polygraph tests to determine a defendant's veracity. ${ }^{46}$ Attaching a person to a machine to force the truth out, the Court reasoned, is "an inadmissible invasion of a person's innermost self and a violation of human dignity." Man should not be "an object of experimentation," a manifestation of the Kantian injunction to treat people as only ends. ${ }^{47}$ Efforts to apply the physical integrity clause outside the criminal context have not, as yet, been successful. The topic of physical inviolability, being mainly a criminal one, will not be addressed in this article.

\footnotetext{
39 The notion of free development of personality is fundamentally a Kantian one.

40 Art. 2(2) GG.

41 Abortion II, 88 BVerfGE 203 (1993); Abortion I, 39 BVerfGE 1 (1975).

42 Schleyer Kidnapping Case, 46 BVerfGE 160 (1977).

43 Chemical Weapons Case, 77 BVerfGE 170 (1987) (right to life clause does not prevent state from approving storage of chemical weapons at army bases). In Mülheim, 53 BVerfGE 30, 57-69 (1979) and Kalkar, 49 BVerfGE 89, 140-44 (1978), the Constitutional Court recognized a state duty to protect life in connection with the threats of a nuclear power plant, but determined that the duty could be met in the manner the government determined.

44 Article 2(2) GG. Kommers (1989).

4516 BVerfGE 194 (1963). See also Pneumoencephalography Case, 17 BVerfGE 108 (1963) (Court invalidated court-ordered puncture of a person's vertebral canal for purposes of testing personality for crime).

46 Polygraph Case, 35 Neue Juristische Wochenschrift (NJW) (375 (1982) (Decision of August 18, 1981). See also 17 BVerfGE 347 (1963).

47 Kommers (1989).
} 
The last of the article two freedoms provides that "The liberty of the individual shall be inviolable." This mainly operates in conjunction with the other article 2(2) freedoms. It too will not be extensively considered here. ${ }^{48}$

Not surprisingly, human dignity, alone or in conjunction with the more particular freedoms of article two, is a rich source of constitutional litigation, and is widely debated on and off the court. ${ }^{49}$ Human dignity in Germany is thus most like the American concept of modern substantive due process, particularly rights of privacy. Both concepts are open-ended and controversial, posing difficult questions for the role of the court within a democracy and the nature of the constitutional order. The remaining part of this article explores this topic as it relates to the development of human personality in Germany.

\section{Aspects of German Personality Rights}

The German Law on the "free unfolding of personality" is comprehensive and multi-faceted. Grounded in human dignity and Kantian philosophy, the right is the only one read in conjunction with another right. ${ }^{50}$ In contrast to human dignity, personality is not an objective value and therefore does not generally operate to impose affirmative obligations on the state.

Personality rights come into play, potentially, whenever an action is not protected by a more specific right. Theoretically, all claims or interests have the potential to be so protected. In this way, article one human dignity and article two (1) rights interact to form comprehensive protection of human personality and personhood. The Constitutional Court captured the sense of these rights well in the Eppler Case:

They complement as "undefined" freedom the special (defined) freedoms, like freedom of conscience or expression, equally constitutive elements of personality. Their function is, in the sense of the ultimate constitutional value, human dignity, to preserve the narrow personal life sphere and to maintain its conditions that are not encompassed by traditional concrete guarantees. ${ }^{51}$

This "catch-all" function of personality rights is especially important in view of "modern developments and the associated threats they pose to the protection of human personality." 52

Textually, comprehensive rights are not clearly derivable from enumeration of a "right to the free development of personality". Still, the fundamental thrust of the German Constitutional Court has been to enlarge the rights sought to be captured by the language, as compared to confining itself to strict application of the language of

\footnotetext{
48 Mainly, this freedom protects free physical movement. It is somewhat akin to the English concept of habeas corpus, protecting against arbitrary restraints on physical liberty. See Pieroth and Schlink (1994).

49 See, e.g., Badura (1964) (examination of roots of dignity concept); Degenhart (1992) (examination of general right of personality); Hofmann (1993) (exploration of capacious concept of human dignity).

${ }^{50}$ Conversation with Professor Dr. Bodo Pieroth, Universität Münster, Münster, Germany (July 8, 1996).

5154 BVerfGE 148, 153 (1980).

52 Right to Heritage I, 79 BVerfGE 256, 268 (1988).
} 
the text. ${ }^{53}$ German personality law is thus a creature of the Constitutional Court, as rights of privacy are of the Supreme Court.

There are two components to German personality law: freedom of action and guarantee of a personal sphere. Freedom of action is outward in focus. As conceived in the seminal Elfes Case, freedom of action empowers one to do fundamentally what one desires insofar as it does not interfere with others or the constraints of the social order. ${ }^{54}$ Essentially, this aspect of personality allows one to define oneself in relation to society.

As freedom of action is outward in focus, the personal sphere is inward in orientation. In comparison to freedom of action, the personal sphere delimits an essential sphere of privacy within which one can fundamentally determine who one is and how one should relate to the world, if at all. One may choose to engage actively in the world, and thus avail oneself of freedoms of action. Or, one may choose to withdraw from the world, retreating into oneself and concentrating on inner development. The Constitutional Court has actively sought to create an inner, intimate sphere so that a core of personality might be developed and protected. The focus on interiority reflects the underlying vision of man as a "spiritual-moral" being. 55

The personal sphere is narrower in dimension than the range of freedom of action. It protects only against incursions that aim to curtail the personal sphere. Just what this means is better elaborated by case law than definition, and the Court has had some difficulty in fixing the concept. ${ }^{56}$ Confidentiality is protected, such as the secret taping of conversations ${ }^{57}$ or the attempted use of divorce records in a work disciplinary proceeding, ${ }^{58}$ as is inquiry into personal matters, as developed in the Census Cases. ${ }^{59}$ The Court, in fact, has sought to delineate a range of tangible rights that map out this private sphere in order to lend structure to personality rights. The German focus on the inner life may reflect the fact that freedom in public life was foreclosed for much of modern history, leaving the inner realm as the stage for freedom. Certainly a German interior life has deep intellectual and cultural roots. Cultural and artistic manifestations of the human spirit have traditionally been prized in Germany. For now, however, these thoughts must await further development. First, we must consider the jurisprudence of the Court so that we will have an empirical basis on which to base such observation. The next part of the article explores the twin inner and outer dimension of German law, starting with the outer dimension as crystallized around the concept of freedom of action.

\footnotetext{
53 Degenhart (1992).

546 BVerfGE 32 (1957). For elaboration of the concept of free development of personality, See Pieroth and Schlink (1994); Degenhart (1992).

55 See, e.g., Elfes, 6 BVerfGE at 36 (essence of man as spiritual-moral person).

56 Criminal Diary Case, 80 BVerfGE 367, 373-75 (1980).

57 Tape Recording Case, 34 BVerfGE 238 (1973).

58 Divorce Records, II, 32 BVerfGE 373 (1972); Divorce I, 27 BVerfGE 344 (1970).

59 Census Act Case, 65 BVerfGE 1 (1984); Microcensus, 27 BVerfGE 1 (1969).
} 


\section{Freedom of Action: The Outer World: Elfes and the General Right of Personality}

German personality law began with the ground-breaking decision of Elfes in $1957 .{ }^{60}$ The setting seemed an odd one in which to announce a general personality right. Elfes was active in right-wing politics, before and after World War II, enjoying some success, including election as a parliamentary representative as a member of the Christian Democratic Union. ${ }^{61}$ In his political activities, he was a severe critic of West German defense policy and its policy toward reunification, having participated in conferences and demonstrations at home and abroad. ${ }^{62}$ Seeking to continue spreading his message abroad, he sought extension of his visa to attend a foreign political conference, but was denied on the ground that his criticism constituted a threat to national security.

Elfes first argued that his activities were protected by article 11, which guarantees Germans freedom of movement. However, the Court ruled that this provision applied only to inter-German travel, not foreign travel. ${ }^{63}$ Thus, if Elfes was to succeed, another argument was necessary. Even if foreign travel was not covered by article 11, it might yet be part of one's personal freedom of action, protected under article two (1), so the Court determined. This illustrates the catch-all function of article two personality rights: they capture claims not protected by the more specific guarantees in the catalogue of basic rights. ${ }^{64}$

By freedom of action, the Court meant the right to engage in activities necessary to the development and assertion of one's person. ${ }^{65}$ Whether traveling abroad constituted freedom of action depended on resolving a theoretical dispute, left open in the Investment Aid Case, ${ }^{66}$ as to the reach of this freedom. In the Investment Aid Case, the Court had laid out two definitions of freedom of action, not choosing one over the other. Freedom of action could mean only a "minimal amount of this freedom of action without which an individual would not be able to develop herself

\footnotetext{
${ }^{60} 6$ BVerfGE 32 (1957). An earlier Constitutional Court case, the Investment Aid Case, 4 BVerfGE 7 (1954), had first begun the process of attempting to fix the definition of freedom of action. But the essential development of a right of personality occurred in connection with the Federal Supreme Court's (BGH), the supreme interpreter of the German Civil Code (BGB), interpretation of the German Civil Code. For example, the Schacht Case, 13 Entscheidungung des Bundesgerichtshofes in Zivilsachen (BGHZ) 334, NJW 1404 (1954). Elfes represented the Constitutional Court's approval of these developments of the $\mathrm{BGH}$, thereby constitutionalizing the doctrine of a general right to personality.

$61 \mathrm{He}$ had been a member of the central committee of the party before 1933, police commissioner of Krefeld in 1927 and mayor of Mönchen-Gladbach, among other political activities: 6 BVerfGE at 32-33.

62 Ibid.

63 There was a long history of limitation of the right to travel abroad for security reasons, which the Court noted. Ibid.

64 Ibid.

656 BVerfGE at 36 ("Seen from a legal perspective, [article 2(1)] is an independent basic right, that guarantees general human freedom of action.").

664 BVerfGE 7 (1954).
} 
as a spiritual-moral person." 67 Or, freedom of action could be interpreted "in a broad, comprehensive sense." 68

In Elfes, the Court decided that a broad interpretation better suited the text and purpose of the Basic Law. First, it seemed inconceivable how a definition limited to the "core area of personality" could ever result in violations of "the rights of others... the constitutional order... or morality," the textual limitations of personality. It seemed hard to envision how these textual restrictions could then have meaning. A broader interpretation thus seemed more sensible. Second, article two reflects radiation of human dignity, the ultimate constitutional value, as do all constitutional principles. $^{69}$ Thus, a broad interpretation seemed more compatible with a view of persons as morally autonomous beings operating responsibly within the community. Third, an expansive interpretation also seemed more consistent with the Framers, who had originally used the language "everyone can do or not do what he or she likes," changing this for "linguistic" reasons, not legal considerations. ${ }^{70}$

A broad interpretation of freedom of action has important consequences for the German constitutional order. As intended by the Court, every form of activity related to personality, in principle, is covered by the concept. Restraints on personal freedom will come only from those imposed as a condition of the "constitutional order" or other textual limitations. ${ }^{71}$ This view thus endows persons with significant personal freedom, transforming the Basic Law into a very rights-protective charter. One might argue it is consistent with the concept of human dignity that infuses the Basic Law, calling on the state, as it does, "to respect and protect it." 72 In practice, however, the Court has limited the reach of this freedom to mainly economic and recreational areas despite the expansive reach of the concept. ${ }^{73}$ Yet, the role of article two as the last preserve of individual freedom is an important principle.

Applying these principles, the Court determined that foreign travel was within freedom of action. ${ }^{74}$ This determination did not, of course, end the inquiry. Freedom of action is guaranteed only to the extent it is within the constitutional order, and does not violate third party rights or morality. ${ }^{75}$ This thus provided the Court with the occasion to interpret these textual limitations. At issue in Elfes was the constitutional order limitation, since security measures are taken to protect society. This is the most important limitation.

\footnotetext{
676 BVerfGE at 36. This is the so-called Core Theory (Kernbereich Theorie), by which is meant protection of only a core of personality that involves the essence of woman as a spiritual-moral person. 68 Ibid.

69 "Certainly the ... formulation of article 2(1) was an emanation of Seeing it in the light of Article one and to derive therefrom its purpose to embody the vision of humankind." Ibid.

70 Ibid.

71 "Restraints on the free development of personality come from the constitutional order." 6 BVerfGE at 37.

72 Article 1(1) GG.

73 Kommers (1989). The Falconry Licensing Case, 55 BVerfGE 159 (1980). Accord, Rider In Woods, 80 BVerfGE 164 (1980).

746 BVerfGE at $41-42$.

75 This is the text of Article two, and as interpreted by the Court. 6 BVerfGE at 36-37.
} 
Rights of others entails the rights and claims of third parties. ${ }^{76}$ Such claims might justifiably limit individual rights in Germany. In German law, this restriction has been employed to ban arson and trespass, for example. ${ }^{77}$ In the context of religious rights, the dignitarian rights of others were used to limit an atheist's attempt to coerce individuals to his view through use of cigarettes as bribery. ${ }^{78}$ However, third party rights are ordinarily evidenced in the legal and constitutional order and, thus, unlikely to act as an independent restraint. ${ }^{79}$

Morality is not self-defining in German law, although German law relies on explicitly Christian law. Still, morality is mainly reflected in legal concepts, like "good morals" (guten Sitten) or "good faith" (Treu und Glauben), ${ }^{80}$ that make up the legal order. As such, and especially with its roots in Kantian thought, morality becomes an important background principle for the legal system as a whole. As a practical matter, however, morality itself will not ordinarily restrain freedom of action. ${ }^{81}$ This brings us back to the "constitutional order," of which much depended on its construction.

According to the Court, the constitutional order means the general legal order as it conforms to the constitution. ${ }^{82}$ One interpretation of this would be that any law consistent with the constitution, at least procedurally, could limit the basic right. While textually plausible, this would effectively render the right meaningless. ${ }^{83}$ Since the Federal Republic was founded as a social-democratic state committed to human dignity, this interpretation seemed inappropriate.

Rather, since the "Basic Law erected a value-oriented order ... the independence, self-determination, responsibility and dignity of individuals must be guaranteed in a political community." 84 Thus, for laws to be consistent with the constitution, they must conform to the value-order of the Basic Law. At the top of this value-order is, of course, human dignity, the ultimate constitutional value. In this context, dignity means, at a minimum, that the "intellectual, political and economic freedom of people may not be limited so that the essence of personhood is impaired." 85 From this it follows "that each citizen is afforded a sphere of private development ... an ultimate inviolable realm of personal freedom, insulated against encroachment by public authorities." ${ }^{86}$ Certainly no law impinging on the "inviolable realm" could be consistent with the Basic Law.

\footnotetext{
76 Pieroth and Schlink (1994).

77 Currie (1994).

78 Tobacco Atheist Case, 12 BVerfGE 1 (1960).

79 Pieroth and Schlink (1994).

${ }^{80}$ Articles 138(1), 242, 826 German Civil Code (BGB).

81 Pieroth and Schlink (1994).

826 BVerfGE at 37-38.

${ }^{83}$ Ibid. This interpretation was the one in vogue under the 1919 Weimar Constitution. But it Seemed inappropriate in view of the value-order constructed in the Basic Law.

84 Ibid.

85 Ibid.

86 Ibid.
} 
Laws must also conform substantively to "unwritten fundamental constitutional principles (of the free-democratic order), as well as the fundamental decisions of the Basic Law, especially the principles of the rule of law (Rechtsstaat) and the social welfare principle." (Sozialstaatsprinzip.) ${ }^{87}$ Through this interpretive technique, the Court introduced significant background and, even, immanent, if not extra-textual, authority. Again, this underscores the Court's proactive interpretive stance and, also, the rich context within which the Basic Law is to be interpreted. The Rechtsstaat principle is especially significant in this regard. Under this principle, laws must give fair warning and fair procedure, not be retroactive, and have a legal basis. ${ }^{88}$ Most importantly, the concept of Rechtsstaat embodies the Proportionality Principle, meaning, in essence, that laws must pursue proper ends through means that are suitable and "proportional" to the ends sought. The Proportionality Principle is akin to means/end testing in American rights analysis, such as that used in heightened scrutiny methodologies. ${ }^{89}$ Both methodologies guard against arbitrary government. Thus, the true impact of the Proportionality Principle is seen in case law, as in America, where it often settles the case, as will be amply seen.

It is thus apparent that the value-oriented nature of the Basic Law influences significantly the nature of the legal order. Laws must conform to this value-order to be part of the "constitutional order." "Constitutional order" is thereby rendered into a two-sided limitation. While the "constitutional order" can limit personality rights, this can occur only when laws themselves conform to the German value-order. In essence, the Court implied a limitation from the structure of the Basic Law on the express textual limitation of article 2(1), itself a notable, but plausible, act of judicial activism. ${ }^{90}$ Significantly, this had the effect of transforming plain constitutional language into an open-ended, general clause. Much will always depend on judicial interpretation of article 2(1).

In Elfes, the Court found that Elfes' interests in foreign travel was part of his freedom of action, but that it was outweighed by the state security interests at issue. ${ }^{91}$ Certainly state security is a justifiable part of the "constitutional order," which might be used in limitation of basic rights. However, the particular state interests at issue in Elfes did not seem particularly well drawn or persuasive. Elfes was an elected official in Germany. His views were well-known, at home and abroad. Thus, it seems unreasonable to find that another foreign trip would place the state in jeopardy. Perhaps the government desired to protect its image abroad. Perhaps it yet feared for the fragility of the new German experiment in democracy. Certainly Elfes seems to reflect the skittishness of the cold-war times.

\footnotetext{
87 Ibid.

${ }^{88}$ Currie (1994). See also Article 19(1) GG, ("statutes [restricting rights] shall apply generally and not solely to an individual case ... (and) name the basic right."). The concept of Rechtsstaat can also be said to embody the concept of meaningful judicial review of official action. Currie, supra note 7, at 19.

${ }^{89}$ Under conventional American doctrine, violations of individual rights trigger strict scrutiny, an inquiry requiring government to justify its regulation as "necessary to serve a compelling state interest and ... narrowly drawn to achieve that end." Arkansas Writers' Project, Inc. v. Ragland, 481 U.S. 221, 231 (1987).

906 BVerfGE at 37-41.

916 BVerfGE at 42-43.
} 
As a seminal case, it is notable that the Court in Elfes did not attempt to set out any comprehensive definition of freedom of action. In fact, there is no case where the Court has defined the full range of personality rights. ${ }^{92}$ Instead, the Court has preferred to work out the specifics of what freedom of action means in concrete cases in view of current or developing social conditions. ${ }^{93}$ Thus, the exact reach of the zone in which individuals may shape their lives awaits case-by-case developments, as in American autonomy law.

However, Elfes did establish the methodology applied by the Court to judge the reasonableness of governmental action seeking to limit personal interests. As applied in Elfes, this methodology is an ad hoc balancing test designed to test the weight of the personal interest against the strength of the official interest. The Court did not engage in any comprehensive review of the lower court decision, preferring to look lightly at the court's results. The Court looked only to see whether the lower court decision had a basis in law. ${ }^{94}$ Certainly the Court was concerned that it not intrude too deeply into the domain of the ordinary courts. It would take later events before the Court would exercise a more intensive review of lower court cases to further fundamental rights.

Elfes is significant in another regard. The techniques employed by the Court illustrate how it has been able to assume its role as guardian of the constitution and, correspondingly, censor of governmental action. The German Constitutional Court thus parallels the role of the Supreme Court over matters that we call substantive due process. In the modern era of human rights, the Supreme Court has judged the reasonableness of official action against the opaque language of "due process of law." Both the German and American Courts have set up legal regimes to anchor such operative terms in more solid ground. In Germany, we have seen how personality rights have become part of a general "freedom of action" limited only by third party rights, morality or the constitutional order. In the United States, the due process inquiry involves a quest for those "basic values implicit in the concept of ordered liberty," 95 which itself involves a reasoned judgment "of respect for the liberty of the individual ... (against) the demands of organized society." 96 In both countries, these decisions are ultimately acts of judicial judgment.

In Elfes, for example, national security interests were held to justify limitations on foreign travel. Likewise, general freedom of actions have been limited by price regulations ${ }^{97}$ and the freedom of action of a horse rider has been limited to assigned bridal paths out of deference to the rights of hikers and bikers to pursue their activities secure from horse traffic. ${ }^{98}$

\footnotetext{
92 Census Act Case, 65 BVerfGE 1, 41 (1984); Kommers (1989).

93 Ibid; Pieroth and Schlink (1994).

946 BVerfGE at 43-44 (court not to apply full-range review, but only look to See whether specific constitutional provisions violated).

95 Griswold v. Connecticut, 381 U.S. 479, 500 (1965) (Harlan J., concurring) citing Palko v. Connecticut, 302 U.S. 319, 325 (1937).

96 Poe v. Ullman, 367 U.S. 497, 542 (1961) (Harlan, J., dissenting).

978 BVerfGE 274, 327-29 (1958).

98 Rider in Woods, 80 BVerfGE 137 (1989).
} 
However, the Court has also invalidated measures for violating the Proportionality Principle. Thus, government cannot prevent persons from trying to arrange drivers for interested riders. ${ }^{99}$ Likewise, parents do not have unlimited power to bind their minor children by contract. ${ }^{100}$ One of the best examples of the Constitutional Court's technique in judging state actions is the Falconry Licensing Case, ${ }^{101}$ where the Court found governmental regulation unreasonable in requiring those engaging in the sport of falconry to demonstrate competence in the use of firearms.

\section{Inner Freedom in German Law: The Personal Sphere}

The flip side of freedom of action is a focus on the interior person. Here the Constitutional Court has posited a "private sphere or ultimate domain of inviolability in which a person is free to shape his life as he or she sees fit." ${ }^{102}$ This domain includes the right to retreat from the world, as one likes, captured as the moralspiritual essence of being, as well as the right to engage actively in the world, as covered by freedom of action. There is not, of course, a clear conceptual line between the inner and outer world. Rather, both are components of an integrated, whole person. Nevertheless, it is notable that German law has accented the interior component of human personality, a focus American law has not, as yet, developed.

\section{Establishment of Interiority in German Law: Microcensus Case}

Focus on the interior component of human personality in German law began comprehensively with the important Microcensus Case, ${ }^{103}$ which concerned the constitutionality of a federal questionnaire or "microcensus" designed to elicit a portrait of the German population. The questionnaire sought information over personal habits, including vacation practices, occupation, standard of living and whether mothers worked or remained home to rear children, among other topics. ${ }^{104}$ In this context, the Court carved out a private, personal sphere for citizens to inhabit free from incursion.

The fact that the statistical survey sought personal information necessitated inquiry into the domain of personal rights protected within article two. Here the Constitutional Court raised the barricade of human dignity, which "the state could take no measure, or enact any law, which would violate ... or otherwise infringe upon the essence of personal freedom as encompassed within the limits of article

\footnotetext{
9917 BVerfGE 306, 313-18 (1964), noted in Currie (1994). Here Professor Currie catalogues a number of cases along these lines.

10072 BVerfGE 155, 170-73 (1986).

10155 BVerfGE 159 (1980).

102 Kommers (1989).

10327 BVerfGE 1 (1969).

104 Ibid.
} 
two." 105 As should now be evident, there can be no greater thunder in the German constellation than invocation of human dignity. The significance of this became immediately clear: "The Basic Law thereby guarantees individual citizens an inviolable area of personal freedom in which one can freely form one's life, the effect of which is to remove all official power (from this realm)." ${ }^{106}$ This is the personal sphere in which one is free to determine and structure one's life. ${ }^{107}$

This intimate sphere is a critical part of the human vision that lies at the root of the Basic Law, bestowing self-worth, social value and respect. ${ }^{108}$ This also shows how concepts of human dignity, humanity and community are interlinked in German law. Through this interaction, dignity takes on a more concrete meaning: "It would be inconsistent with human dignity for the state to force people to register and catalogue their whole personalities, even if done anonymously through a statistical survey, and thereby treating man as an object, which is accessible in every manner." 109 Insistence on respect for human dignity is thus instrumental to preservation of human autonomy.

With this background, the Court went on to elaborate the Inner Sphere.

Such a (pervasive) penetration in the personal area through a comprehensive inspection of the personal relationships of a citizen is also denied the state because individuals must have an Inner Space (Innenraum) in which to develop freely and self-responsibly their personalities, an Inner Space in which they themselves possess and in which they can retreat, banning all entrance to the outer world, in which one can enjoy tranquility and a right to solitude. $^{110}$

The presence of an ascertainable Inner Space in German personality law is a notable achievement. It is wholly a creation of the Constitutional Court, in pursuit of its perception of the vision underlying the Basic Law. Textually, it is certainly not self-evident that "the dignity of man" or "the right to the free development of his personality" would yield this emphasis. Rather, it reflects the Court's desire to preserve and protect the integrity of human personality, especially in applying the concept of human dignity to meet changing social conditions, such as the development and use of computer technology in Microcensus. In this way, human autonomy and capacity are safeguarded and nourished against the challenges posed by modern social, economic and technological change. Considering that law is a reflection of culture, it is interesting to decipher the cultural traits evidenced by this German accent on the interior life. For one thing, this focus is quite compatible with German history and culture, which has placed extraordinary emphasis on the world

\footnotetext{
105 Ibid.

106 Ibid.

107 For this proposition, the Court, significantly, cited Elfes, 6 BVerfGE at 41.

108 "In the light of this image of man at root in the Basic Law, the human achieves social value and respect in society." 27 BVerfGE at 6.

109 Ibid. These sentiments evidence, unmistakably, the influence of Kant.

11027 BVerfGE at 6 . The Court observed that even the presence of a neutrally devised state inspection scheme could violate the right to personality because it would induce psychological pressure. Ibid.
} 
of the mind and of the artist. Emphasis of culture has predominated over public life through most of German history. The German emphasis on interiority also reflects, again, Kantian thought, and its emphasis on the autonomy of the individual and the unfolding of human capacity.

As a matter of doctrinal law, the Constitutional Court's carving out of a private, intimate sphere has produced distinct strands of personality law. Perhaps most notable is the general control over personal information that has resulted in a right to informational self-determination. Related to informational self-determination is the right to control over portrayal of one's person, including rights to one's own image and spoken word and rights, in some circumstances, not to have false interviews or statements attributed to one's person. But we are getting ahead of ourselves, as these are all matters meriting separate development later. What is significant for our purposes is that the German strand of interior personality has led to a distinct evolution of personality law, one quite different from American law.

In reference to Microcensus, the question for the Court was whether this "microcensus" so deeply impinged upon this sphere of intimacy as to violate article two personality rights. Certainly "not every statistical survey of personal data violates personal dignity ... or disturbs self-determination over the innermost (private) areas of life." ${ }^{111}$ Characteristic of the German regime of rights, everything is a question of balance and proportion. No one's right is extended to the detriment of other rights. Thus, personality rights-even over intimate areas-are mediated in relationship to other values of the social order. One's obligations as "communityconnected and community-bound" citizens entail a certain cooperation with officials in matters that call for state-planning, like a census. ${ }^{112}$

This inquiry necessitates a closer evaluation of the case. Survey questions principally threaten self-determination rights when they impinge upon the "personal intimate area of life, which by nature is confidential." For "the modern industrial state, this is a barricade to prevent administrative-technical depersonalization."113 However, statistical surveys inquiring only over human behavior will not generally violate the intimate realm. This is especially so when anonymity is used, as in the Microcensus survey, since this obscures any personal connection, thereby hindering, if not preventing, any catalogue of human personality. ${ }^{114}$

In Microcensus, the key issue turned on inquiry into vacation and recreational habits. While such inquiries implicate the private sphere, they do not "force disclosure of information arising from one's intimate sphere, nor allow the state access to relationships that are ordinarily beyond outside scrutiny or of a confidential nature." ${ }^{115}$ This type of information could be obtained from general sources, "although with greater difficulty." 116 Thus, the inquiry did not constitute a

\footnotetext{
11127 BVerfGE at 7.

11227 BVerfGE at 7.

113 Ibid.

114 Ibid. Moreover, as additional precautions, the statute prohibits publication of information gathered and binds census takers to confidentiality.

115 Ibid.

116 Ibid.
} 
constitutional violation. Likewise, resort to the Rechtsstaat principle did not yield relief, since the legal norms at issue were sufficiently definite and the measures taken satisfied the Proportionality Principle, being suitable means to accomplish legitimate ends. ${ }^{117}$ Microcensus thereby illustrates the same methodology used by the Court in the outer-directed freedom of action cases: evaluation of the intensity of the rights violation, and then testing of the case against Rechtsstaat principles, especially that of proportionality.

\section{Criminal Diary Case}

Determining to construct a sphere of inviolable privacy is one thing. Defining exactly what it is is another. The best more recent attempt to come to grips with these existential questions is the Criminal Diary Case, where the Court grappled with the question as to whether the state could use diaries of a young man accused of murder as proof in its case. ${ }^{118}$ The man had a life-long problem in forming relationships with women, which he was in therapy to help deal with. The therapist recommended that he write down his inner struggle in a diary. The diaries revealed his innermost feelings and insecurities over his inability to form relationships with women. During a search of the home of his parents, where he lived, the police discovered the diary. The diary entries bore certain similarities to the murder the man later became accused of. Because of their relationship to the crime, the state sought to use them as circumstantial proof in its case. ${ }^{119}$ The essence of the legal dispute was whether the diary entries were portals into the innermost feelings of the defendant and, therefore, protectable as part of the intimate realm of article two personality. In fact, the Federal Supreme Court (Bundesgerichtshof or BGH) believed just this-that the intimate nature of the diaries made them part of the defendant's protected personality rights, but that their use in a criminal trial was justified by the important public interest in solving a serious crime. ${ }^{120}$ Criminal Diary thus provided the Constitutional Court with a good opportunity to bring some clarity to the personal sphere.

"The general personality rights anchored in articles one and two guarantee ... control over ... personal details of one's life," the Court announced, referring to the fundamental right of informational self-determination established in Microcensus and secured in the Census Act Case. ${ }^{121}$ But even here, the "protection is not absolute," but can be limited by "overriding public interest." 122 This follows from individuals' obligations to the community and its members. ${ }^{123}$

\footnotetext{
117 Ibid.

11880 BVerfGE 367 (1980).

119 Ibid.

120 Ibid. In this respect, the BGH upheld the decision of the lower court.

12180 BVerfGE at 373. See Census Act Case, 65 BVerfGE 1, 41 (1984).

12280 BVerfGE at 373.

123 This reflects the German vision of woman as socially-connected and bound. "Limitation of freedom can occur when justified by overriding public interest, because individuals enter into communication with others in the social community, and their conduct effects others and can disturb the personal sphere of others or the interests of the community." Ibid.
} 
Nevertheless, "even overriding public interest" might not justify intrusion into this most intimate sphere. ${ }^{124}$ On account of the human dignity anchor, the Court postulated a certain ultimate core of personality from which all official entry is barred. ${ }^{125}$ Here it was unnecessary to perform any proportional means/end testing. Certainly only truly innermost matters would enjoy such protection.

To the extent a personal matter is not characterized as being of the innermost "inviolable area," it might be counted as part of the personal sphere into which "significant public interests" might be allowed entry. ${ }^{126}$ Thus, much depended on how personal matters, like the diary entries, were to be characterized.

The topic of an innermost personal sphere, and how to define it, has been a focus of much controversy. ${ }^{127}$ Early on the Court set forth the Sphere Theory (Sphärentheorie), under which human personality interests were calibrated according to the intensity of their intimacy. Different levels of constitutional protection were assigned the interests according to this scheme. For example, the most intimate sphere (Intimsphäre) was the "last, inviolable area of human freedom ... from which all public power was disseized." ${ }^{128}$ Aspects of sexual determination, such as one's sex, ${ }^{129}$ sex education ${ }^{130}$ or the marriage bedroom, ${ }^{131}$ are examples of interests held to be within this most intimate sphere. Next in concentric order was a private or confidential sphere (Privat or Geheimsphäre) that was subject to the textual limitations of article two(1). ${ }^{132}$ In this sphere, personality rights could be curtailed only under hard proof of their necessity under the Proportionality Principle. Vacation and recreational habits ${ }^{133}$ were examples of interests grouped in this sphere. The last sphere was an outer or social sphere (Sozialsphäre), which comprised interests connected closely to society which had little intimate character. Actions could be taken to curtail exercise of interests under less exacting standards of proof. Examples of these interests were information leading to the solution of a crime or disease, such as an epidemic. ${ }^{134}$

Not surprisingly, serious definitional problems arose as to the boundaries of these spheres, and the grouping of interests within them. The spheres could not be adequately distinguished, and people classified interests differently, leading to a

\footnotetext{
124 Ibid. This follows from Article 19(2) GG, which protects the essence of a right. As the essence of the right of personality, the Court has postulated a certain inviolable core of personality, as discussed here. Ibid.

125 Ibid. "The Court has recognized a last inviolable area of private life formation from which all public power is disseized." Ibid.

126 Whether this is so or not would depend on means/end testing pursuant to the Proportionality Principle.

127 See Pieroth and Schlink (1994); Degenhart (1992).

128 Ibid. citing 38 BVerfGE 312, 320; Elfes, 6 BVerfGE at 41.

129 Transsexual Case, 49 BVerfGE 286 (1978).

130 Sex Education Case, 47 BVerfGE 46, 71 (1977).

13127 BVerfGE 344 (1970).

132 Pieroth and Schlink (1994).

133 Microcensus, 27 BVerfGE at 1.

134 See, e.g., Criminal Diary Case, 80 BVerfGE at 375-77; Lebach, 35 BVerfGE 202, 220 (1973) (noting strong state interest in solving crime); See von Mangoldt et al. (1985).
} 
certain relativism of the theory. ${ }^{135}$ Moreover, the main criterion used by the Constitutional Court-social Connectedness_-proved unworkable as a legal standard since legal regulation always involved a considerable social element, whether in conduct, action or communication. ${ }^{136}$

For these reasons, the Court abandoned the Sphere Theory in the Census Act Case. ${ }^{137}$ Since that abandonment, however, no satisfactory replacement theory has been forthcoming. ${ }^{138}$ In fact, the Sphere Theory continues to provide a certain structure to this inquiry, even if as a background concept, as is evident in the Court's discussion in Criminal Diary. This is especially pronounced in matters involving an aspect of retreat from the world, such as, for example, the act of writing diaries in Criminal Diary. The Court's ventures may ultimately prove to be an example of the limits of Grand Theory, not unlike similar quests in service of the first amendment. ${ }^{139}$

This brings us back to the Criminal Diary Case, which marks the last great attempt of the Court to define an innermost sphere. ${ }^{140}$ "Whether a matter is to be characterized as within the core area ... depends on whether it is of a highly personal nature and the degree and intensity with which it affects the interests of others or the community." ${ }^{141}$ If this works fine. But the standard seems no more self-defining than the old Sphere Theory. Indeed, it seems to call for an ad hoc weighing of personality versus social interests, thus repeating the relativism of the former theory. Because of these difficulties, the Court has renounced Grand Theory, at least for now, preferring to work out what is "personal" or "intimate" on a case-by-case basis. ${ }^{142}$ Thus, from the standpoint of today, the extent of the inviolable sphere can only be determined by its delineation in case law.

Applying these principles proved no more satisfactory than defining them. The Court split 4-4 on whether the diaries were part of an innermost personal sphere. ${ }^{143}$ The quartet of Justices believing the diary entries were not private enough focused on their social connection. Because the diaries helped explain a gruesome crime, they reasoned, they bore a clear connection to societal interests and did not partake of any intimate thought, since they were written, and thus discoverable, and since the acts were already performed. ${ }^{144}$ Moreover, use of the diaries as proof in a serious crime provided a "significant public justification." 145

\footnotetext{
135 Degenhart (1992); Pieroth and Schlink (1994).

136 Ibid.

13765 BVerfGE at 45.

138 Letter of Professor Dr. Bodo Pieroth to Edward J. Eberle (November 13, 1996).

139 Eberle (1992).

140 Letter of Professor Dr. Bodo Pieroth to Edward J. Eberle (November 13, 1996).

14180 BVerfGE at 374. This marks a renunciation of focusing solely on "social connectedness" as the distinguishing factor. "The ordering of matters within the inviolable area ... or the area of private life ... can no longer depend on the social significance or connection of the matter." Ibid.

142 "What type and how intense a matter is ... cannot be described abstractly, but can be satisfactorily determined only upon a full consideration of all relevant factors in a particular case."Ibid.

143 Under German law, a tie vote results in the lower court ruling remaining in effect. See Federal Constitutional Court Law (BVerfGG) Sect. 15(3).

14480 BVerfGE at 376-77. The Court did not find any general protection for diaries. Therefore, much depended on the contents of the diaries, and how one valued it.

145 Ibid.
} 
The four dissenting Justices, by contrast, believed the diaries to be "highly personal," reflective of the defendant's "real personality structure ... a dialogue with the real I." 146 Indeed, it is hard to imagine many acts more intimate than recording one's innermost thoughts in a diary, especially when done in the belief of confidentiality, particularly that of the doctor-patient relationship. Thus, for these Justices, the diaries should be protected as within the personal sphere. Moreover, they argued, the crime was removed 17 and 8 months, respectively, from the two diary entries most at issue. ${ }^{147}$ Thus, any connection to the real world was remote.

There is certainly an unsatisfactory quality to the Court's analysis. Reliance on the ad hoc balancing test may be too unprincipled, allowing each judge to see personality or community interests as he or she wishes. There would seem to be particular pressure to act on community interests, such as crime, to the detriment of minority interests. Certainly the haphazardness of this case-by-case approach is a danger to legal security. It will take some time before organizing principles are evident around which the law may be structured. In the interim, however, there will be great uncertainty. Because lower courts or other decision makers will not be sure which standards to apply, this carries a risk of curtailing freedoms.

\section{Informational Self-Determination}

The most notable manifestation of the concern, expressed by the Court in Microcensus, of preserving an intimate realm to life is the concept of informational self-determination. This means, fundamentally, a right to control access to and dissemination of personal data, including protection against revelation of one's private affairs. It is rooted in a desire to preserve the integrity of human personality against the onslaught of the technological age and of prying eyes. Thus, the Court has sought to carve out an area of inviolable human interiority as a secure haven. In a sense, this represents adjustment of the Kantian ideal of moral autonomy to the conditions of the modern age.

Building on Microcensus, the Census Act Case ${ }^{148}$ strives to preserve the inviolability of human personality amidst revolutionary changes in the computer age. The controversy concerned the Federal Census Act of 1983, which required the collection of comprehensive data concerning the Federal Republic's demographic and social structure. The Act set the parameters for the country's population count and also required rudimentary personal information, such as name, address, gender, marital status, nature of household occupants, religious affiliation, job occupation and work setting. ${ }^{149}$ The Act also required citizens to fill out detailed questions concerning their sources of income, educational background, mode of transportation to and from work, use of dwelling, including method of heating and utilities. ${ }^{150}$ The

\footnotetext{
146 Ibid. Accordingly, these Justices believed that the diaries should be "absolutely protected as within the area of private life-formation."

147 Ibid.

14865 BVerfGE 1 (1984).

149 Ibid.

150 Ibid.
} 
Act further allowed information obtained to be transmitted to local government, which could then use the information for purposes of planning, environmental protection and redistricting. Local government could even compare information to housing registers and, if necessary, correct them. ${ }^{151}$

Over 100 persons filed suit against the Act, complaining that the Act's intrusiveness threatened their privacy rights. ${ }^{152}$ The Court agreed, at least temporarily, and suspended the census until its constitutionality could be determined. The case is one of the few times when individuals may directly pursue claims to the Constitutional Court without having to exhaust legal remedies because of an immediate threat to a fundamental right.

At the heart of Microcensus and Census Act is the concern that intrusive and comprehensive surveys of the population will yield personality profiles which, with the aid of modern computing techniques, will facilitate the state's ability to access such information at will and use it as seen fit. From the Kantian perspective, this carries the danger of converting human beings into mere objects of statistical survey, depersonalizing the human element. From the standpoint of human autonomy, the Court feared that gathering, storing and using personal information would threaten human liberty. The more that is known about a person, the easier the person is to control. ${ }^{153}$ These concerns are especially heightened with the advance of modern computing technology and its capacity to access human habit and capabilities, which the Constitutional Court made a point of noting. ${ }^{154}$ The amount of personal information stored in and accessible by computers is staggering, including information over credit history, taxes, social security and travel plans. ${ }^{155}$

The background of German personality law provides the theoretical base for these concerns. Since the "focus of the constitutional order ... is the value and dignity of the person, who operates in free self-determination as a member of a free society," these values must be sustained "in view of modern developments and their accompanying threats to human personality." 156 Human dignity must be adapted amidst changing economic and social conditions if human personhood is to remain inviolate in modern society. In this way, the Constitutional Court acknowledges that changing social conditions require adaptation in the application of core concepts.

Just this motivation led the Constitutional Court to announce a general right of informational self-determination. By informational self-determination is meant "the authority of the individual to decide fundamentally for herself, when and within

\footnotetext{
151 Ibid.

152 Kommers (1989).

153 Schwartz (1989).

154 Since the 1969 decision of Microcensus, the Court observed, the advance of computer technology and capability has changed radically. Before, information was entered manually by key-punch and stored in separate areas, accessible mainly by expert personnel, making it more difficult to fashion together and obtain a personality "portrait." Today, information is entered and retrievable electronically by almost anyone, which facilitates instantaneous access to far-ranging information. 65 BVerfGE at 4, 17, 42.

155 Schwartz (1989).

15665 BVerfGE at 41.
} 
what limits personal data may be disclosed." 157 "(T)his decisional authority requires a special measure of protection under present and future conditions of automatic data processing." ${ }^{158}$ For example, "the technological capability of storing (highly) personalized information concerning specific people is practically unlimited and retrievable in seconds ... without concern for distance." "(T)his information, when connected to other data sources ... can produce a complete or partial personality profile, which the affected individual cannot control or confirm its truth." 159 "The possibilities of acquiring information and exerting influence have increased to a degree never previously known." 160

This rise in technological capability poses severe threats to human personality and human autonomy. "An individual's right to plan and make decisions freely may be severely curtailed, if she does not know or cannot predict adequately what personal data is known or may be disclosed." ${ }^{161}$ It is unhealthy for society "where citizens do not know who knows what about them, and when they know it." ${ }^{162}$ Not knowing others' knowledge of your affairs may lead citizens to curtail their activities or "refrain from exercising rights ... like associational rights," or expression, religious or occupational freedoms. Certainly official possession of detailed personal information carries a serious threat of abuse, including coercion and manipulation of human autonomy. ${ }^{163}$ "This would damage an individual's personal development, and also the common good, because self-determination is an elementary condition of a free democratic society based on citizens' ability to act and to participate."164 Accordingly, data use that has the potential to influence people must be strictly controlled. Against these dangers, "an individual must be protected against unlimited collection, storage, use and transmission of personal data ... as a consequence of the free development of personality under modern conditions of data processing." 165 In essence, informational self-determination follows from human autonomy; in the modern information age, control of information is power. Thus, control over personal information is the power to control a measure of one's fate. This is indispensable to the free unfolding of personality.

The right to informational self-determination, like all basic rights, is not absolute in the carefully calibrated value order of the Basic Law. ${ }^{166}$ Since persons "develop within the social community ... personal information is also a reflection of social

\footnotetext{
157 Ibid. As the Court noted, the concept of informational self-determination emanated from earlier cases too, such as Lebach, 44 BVerfGE 353, 372 (1973); Divorce Records, 32 BVerfGE 373, 379 (1972); and Microcensus, 27 BVerfGE at 350. 65 BVerfGE at 42.

15865 BVerfGE at 42 .

159 Ibid.

160 Ibid. Such use could induce psychological pressure to conform, out of fear of how others might employ such personal information. Ibid.

161 Ibid.

162 Ibid.

163 Ibid.

164 Ibid.

165 Ibid.

166 Ibid.
} 
reality." ${ }^{167}$ Thus, there is a social dimension to personal data too, posing a tension between personal and social components to information. Government and other actors in society, such as banks or companies, need information about people to plan and serve the public weal. Democracy itself depends on the free flow of information. ${ }^{168}$ "The Basic Law ... has resolved the tension between individuality and society by constituting individuals as community-bound and community-related." ${ }^{169}$ Therefore, "individuals must ... accept limitations on their right to informational selfdetermination for reasons of overriding public interest (überwiegenden Allgemeininterresse). ${ }^{170}$ Just what an "overriding public interest" is can only be determined by resort to standard German norms. First, the law must have a (constitutional) legal basis, which makes clear the conditions and reach of the limitations on freedom and thereby satisfies the Rechtsstaat command that norms be clearly stated. ${ }^{171}$ Second, the law must satisfy the Proportionality Principle, which, as we know, mandates that freedom be limited only to the degree necessary to satisfy public interests. Because "of the dangers of automatic data processing ... the legislature must, more than ever, adopt organization and procedural safeguards to diminish violations of individual personal rights." ${ }^{172}$ Only then can one test the strength of the public interest.

Testing the Act against these principles entailed a detailed and comprehensive analysis. First, the Court evaluated whether the information was actually necessary. ${ }^{173}$ This involved testing legislative ends. The Court concluded that it was legitimate to perform a census for social and economic planning. ${ }^{174}$ However, collection and storage of data for other purposes would be constitutionally suspect. The Court "carefully scrutinized the nature of the information collected, the methods of its storage and transmission, and its particular uses" in order to assure that the stated uses properly fell within police powers and did not pose undue threat to human liberty. ${ }^{175}$ Protection of information thus depended on a distinction "between personality-related information that is gathered and processed in an individually non-anonymous manner and data that is census-related." ${ }^{176}$ Protective measures must be in place to assure that personality profiles of individuals cannot be obtained. Cloaking information in anonymity is the key safeguard. Persons are not to be treated as "mere information-objects;" individuals are not to be depersonalized as information sources without losing their essence as "spiritual-moral" persons. ${ }^{177}$ Other safeguards included confidentiality obligations and a prohibition

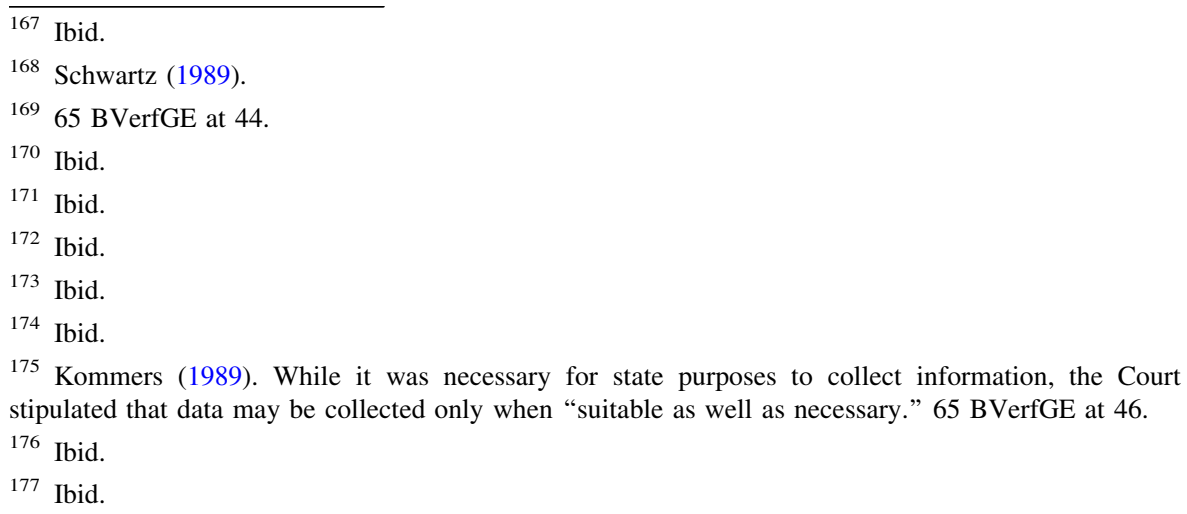


of employing census takers in locales where they lived. ${ }^{178}$ The Court ultimately sustained most of the Act, although it invalidated several provisions, including one that allowed local officials to "compare census data with local housing registries" on the ground that combining these statistics might allow officials to identify particular persons, thereby violating the core of personality. ${ }^{179}$

In the wake of Census Act, it is worth observing what a remarkable act of judicial activism the case represents. ${ }^{180}$ First, the Court suspended the Act until its constitutionality could be determined, ultimately requiring the German Bundestag (Parliament) to amend certain provisions before the census could be carried out. This delayed the census for 4 years at notable cost. ${ }^{181}$ Second, the Court established concretely a right of informational self-determination from the textual authority of articles one and two. That language, of course, does not self-evidently bestow citizens' control over personal data. Rather, the Court extended the principle animating the provisions to carve out this radiation of autonomy. At the root of the Constitutional Court's decision was the vision that human dignity and autonomy must be preserved against the onslaught of the modern computer age. Thus, measures need be taken to assure that the collection, storage and use of personal data is justifiable pursuant to the Rechtsstaat, and that this power not be abused.

\section{Reputational Interest}

A more innovative aspect of informational self-determination is the right it endows individuals to control the portrayal of facts and details of their life, even if uncomfortable or embarrassing. This right empowers persons to shield hurtful truths from public scrutiny in order to safeguard reputation or other personality interests. The right also encompasses protection of personal honor as an outgrowth of personality. ${ }^{182}$ As such, these rights can be extended to eclipse other basic rights, including, most notably, article five expression guarantees.

\section{Mephisto}

Protection of honor and reputation in Germany is itself a highly valued manifestation of human dignity. No case represents this view better than the

\footnotetext{
178 Ibid.

179 Ibid.

180 Since Census Act, government and courts have generally striven to meet the challenges of the case and conform the law to constitutional standards. The German judiciary has invalidated laws that do not adequately spell out projected uses of data or grant citizens satisfactory inspection rights. Schwartz (1989).

181 Kommers (1989). After Census Act, the government decided to abandon the census. Instead, the Bundestag drafted a new census bill, which the Constitutional Court approved. See, e.g., BVerfGE, NJW 707 (1989); BVerfGE, NJW 2805 (1987).

182 There is a long history, going back to the early twentieth century, of civil court protection, through interpretation of the Civil Code, of such privacy rights. Thus, as noted previously, the Constitutional Court has "constitutionalized" most of these developments of the civil court. See Krause (1965).
} 
famous Mephisto case, a seminal case of artistic freedom, where the Court split 3-3 in upholding an injunction against publication of Klaus Mann's novel of the same name on the ground that it defamed the memory of a famous deceased actor who had been quite active in the theater during the Nazi time. ${ }^{183}$

All basic rights, including artistic rights, must be interpreted within the value order of the Basic Law, according to the Court. Since the Basic Law is founded on the view "of the human person as an autonomous being developing freely within the social community," 184 artistic freedom must be measured against article one human dignity, the supreme value. To the extent artistic or communication freedoms conflict with human dignity, they may have to yield, depending on the concrete balancing of the freedoms at issue. For example, in Mephisto, it might be argued that the tangible effect of Mann's novel was to tarnish the memory of the deceased actor. Disparagement of the dead could be thought to be inconsistent with human dignity. ${ }^{185}$ " $[\mathrm{A}] \mathrm{n}$ artist's use of personal data about people in his environment can affect their social rights to respect and esteem." 186 To that extent, communication freedoms may have to yield to the superior value of dignity, as manifested in this interest in honor and reputation. In this manner, the Court implied limits on the seemingly boundless guarantee of artistic freedom, as it previously had implied limits to the seeming express limitation of personality rights in Elfes. In both cases, the Court acted on behalf of its vision of human dignity; in Mephisto this acted to limit expression rights, in Elfes it limited restriction of freedom of action. Human dignity thus becomes the glue between both rights-enhancing and rights-constricting interpretations. Certainly this illustrates the Constitutional Court's creative interpretation, as the Supreme Court too has sometimes displayed. ${ }^{187}$

Anchoring reputational rights in the malleable concepts of human dignity, and accompanying personality, allowed the Constitutional Court, in essence, to imply a constitutional right to be free from defamation. This could be justified from the "objective" theory of constitutionalism, requiring the state, as it does, to realize the norms of the value order. ${ }^{188}$

\footnotetext{
18330 BVerfGE 173 (1971). The central character of the novel was an actor named Hendrik Höfgen, whom Klaus Mann, the son of the great German writer Thomas Mann, portrayed as having made his name by playing the devil in Goethe's Faust during the Nazi period. While other artists were prosecuted, Höfgen "betrayed his own political convictions and cast off all ethical and humanitarian restraints to further his career by making a pact with ... (those in) power in Nazi Germany." Ibid. The story was based on a real life actor, Gustaf Gründgens, whose career paralled the fictitious Höfgen in important respects. The suit was brought by Gründgens' son to protect the honor and dignity of the dead, illustrating the extraordinary protection afforded honor in Germany.

18430 BVerfGE at 193, translated in Kommers (1989).

18530 BVerfGE at 194. For discussion of rights of personality extending after death, See Hubmann (1967).

186 Ibid.

187 See, e.g., Griswold v. Connecticut, 381 U.S. 479 (1965) (deriving right of privacy from penumbras that emanate from specific rights).

${ }^{188}$ Eberle (1999).
} 


\section{Observations}

Having evaluated human dignity and personality in German constitutional law, Germany accords broad freedom to individuals to shape their destiny, while balancing individual aspiration against the demands of maintaining social order. The Constitutional Court acts in an activist capacity to shape these freedoms against the clutches of majoritarian control. The German vision, set out with reasonable clarity, reflecting the systematization of German legal science, centers around the human person as a "spiritual-moral" individual, and her dignity, including especially her ability to realize human capacity and satisfaction. Human values are thus the focal point of the legal order.

The German value order, grounded in the underlying philosophic thought of Kant, reflects a careful calibration of rights and responsibilities, interpreted by the Constitutional Court as an "objective value-order," one that must apply generally in society, effecting all legal relationships. Since human dignity is the apex of this value structure, it naturally radiates throughout the legal system, in public and private law. An essential part of human dignity is basic rights, and corresponding obligations.

While basic rights are mainly defensive or subjective in function, connoting a personal sphere of liberty, only rarely is such subjective liberty a matter of complete discretion. Instead, personal liberty is subject to limitation by the constitutional order, textually secured through express reservation or by necessary implication. ${ }^{189}$ In this sense, rights are limited by obligations to others, as made manifest through the law. Yet, limitations of liberty are themselves not a matter of parliamentarian discretion or social control. Rather, liberty may be restrained only upon justification pursuant to the value order. ${ }^{190}$ In this sense, dignitarian morality acts as the "higher law" of German constitutionalism. ${ }^{191}$

German concepts are reasonably well thought out, constituting an integrated whole, reflecting again the classification and comprehensiveness of German legal science. There is an inner dimension, focusing on the "moral-spiritual" essence of man, and there is an outer dimension, reflecting women's activity in the world. Both dimensions, of course, radiate from the same source of human dignity.

German personality law reflects the broad themes of German law: human dignity and its cognates, including valuation of life as an end in itself, worth and equal worth, and freedom to act within the constraints of the value order. Foremost among these is the focus on the interior component of human personality, an emanation of the inner striving for freedom. Through its jurisprudence, the Constitutional Court has attempted to capture, and preserve, the essence of human personhood and personality, and safeguard it amidst the challenges of modern society. Hence, the Constitutional Court seeks to identify, and fortify, an Inner Space, "in which to

\footnotetext{
189 See, e.g., Articles 2 and 5 GG.

190 In all cases, the essence of the right must be preserved. Article 19(2) GG.

191 By higher law I mean all actions must be judged for conformity with dignity, as the dispositive norm of the Basic Law's value order. Note, for example, the contrasting effect of human dignity in Elfes and Mephisto.
} 
develop freely and self-responsibly ... personalities ... (into) which (people) can retreat, barring all entrance to the outer world, in which one can enjoy tranquility and a right to solitude." 192 The Census Cases, by limiting official use of personal information on account of human autonomy, show how such nurturing of human personhood can make a difference with respect to modern social and economic developments. $^{193}$

While the Census Cases are the most dramatic illustrations of this strand of interiority, the Constitutional Court has carved out related emanations of human personality, in limitation of political and social forces, in service of the inner person. Most notable here is the right to control personal information, crystallized into a general right of informational self-determination. Intimate information reflects human personality, according to the Court, being an ingredient to conception of personhood, from inside and outside perspectives. Accordingly, the person participating in this aspect of "life-formation" should have a measure of control over these matters. Based on this reasoning, the Court has extended degrees of protection over personal data, ${ }^{194}$ honor and rights to one's good name. ${ }^{195}$

The German vision reflects careful ordering of the characteristics of human personhood, especially those called upon in social intercourse, to facilitate wellbeing. Freedom to develop human capacity is sought, indeed encouraged, to the maximum extent compatible with the freedom of everybody else. Thus, moral obligation and respect for others requires that freedom be exercised within the bounds of community. In this view, freedom can truly exist only with provision for well-being, mutual toleration and respect. It is in this sense that the "human person is an autonomous being developing freely within the social community." 196 She is not "isolated and self-regarding," but "related to and bound by the community." 197 Thus, individual self-determination is offset by responsibility, civility and participation.

Viewed in this light, the German vision of constitutional democracy serves as an alternative strategy to organize society, one reflecting the benefits, perhaps, of added perspective and experience. There are obvious indigenous influences that led to the erection, and make-up, of the German value-order, especially to empower and guide personal decision-making. Kantian philosophy and nineteenth century German legal science are decisive theoretical influences. The German experience with anarchy during the Weimar Republic and of dehumanization during the Nazi period, including severe limitation of human personality and capacity and, even, annihilation of life itself, are crucial histories. The erection of the German valueorder may, in fact, reflect a desire to channel human behavior out of fear of the evil that might arise (again) from unchained human passion.

\footnotetext{
192 Microcensus, 27 BVerfGE at 6.

193 Lebach, and its concern for rehabilitation of a felow evidences this too.

194 See, e.g., Census Act, 65 BVerfGE 1 (1984).

195 Mephisto, 30 BVerfGE 173 (1971).

196 Mephisto, $30 \mathrm{BVerfGE}$ at 193.

197 Life Imprisonment Case, 45 BVerfGE 187, 227 (1977).
} 
The Constitutional Court is aggressively activist. The Constitutional Court actively sets out to realize in society the values of the Basic Law, attempting to coordinate constitutional text with social reality. The wholesale rewrite of legislation in the Census Cases attests to this. The Constitutional Court thus acts somewhat more like the US Supreme Court did in the first third of this century under the substantive due process regime, censoring governmental actions, where necessary, for reasonableness. In this way, the Basic Law, as interpreted by the Constitutional Court, acts like a blueprint for society, whereas the American Constitution is more like an outline of government. The German Court places a premium on the text of the Basic Law, its structure and purpose, and its applicability to current social and economic conditions. The Constitutional Court openly makes use of background principles, not always clearly set out in constitutional text, such as the rule of law, the Social State Principle and, of course, the capacious concept of "human dignity." The Constitutional Court actively attempts to maintain the essence of constitutional concepts while keeping constitutional text "in tune with the times." 198 Recall, for example, the Constitutional Court's attempts to preserve the principle of human dignity amidst a changing world in the Census Cases, in relation to changing computer technology. In these ways, the Constitutional Court is forward in focus, whereas the Supreme Court looks backward.

From these differences in constitutional vision, technique and doctrine, we can extrapolate deeper differences in legal culture. The German prioritization of human dignity raises moral autonomy to the forefront of society; it is the higher law of German constitutionalism. Thus, persons have expansive freedom to act and to develop human ability, but that freedom is coupled with a concern for wellbeing, including solidifying the inner realm of personality. Moral autonomy, moreover, is not a one-way street; it involves responsibility too, including to others which one must recognize, even if through enforcement of the moral order. Accordingly, freedom is to unfold within the social community, which can both empower and limit human activity, depending on resolution of the conflict between individual and social claims. ${ }^{199}$ Rights are thus exercised within a framework of duties and responsibilities, mediated ultimately by the Constitutional Court's interpretation of this higher law.

Through examination of these contrasting constitutional visions, we discover alternative conceptions of humanity, personality and community, as outlined in public law, conceptions that can be enriching, ennobling or both. Perhaps this is the central purpose of comparative law: we learn, by looking at others, important truths about ourselves, truths which can then be re-evaluated or reaffirmed. Certainly there is much to learn about the two laws, much the two laws can learn from each other. For example, the Census Cases demonstrate a sensible way to preserve the inviolability of personhood, and human freedom, amidst dramatic technological change. In addition, if Americans want to pursue a more coherent vision of community, the German method of coupling rights with duties, individually and

\footnotetext{
198 Griswold, 381 U.S. at 522 (Black, J., dissenting).

199 Compare, for example, Mephisto, 30 BVerfGE 173 (1971) with Transsexuality, 49. BVerfGE 286 (1978).
} 
socially, points the way toward introducing communal values into the social order. Through attempting to secure human dignity for all, we would perhaps be less preoccupied in securing our own claims. In this way, we might escape our obscession with "rights-talk" and learn to appreciate the value of human solidarity.

Conversely, if dignitarian rights are justifiably viewed as indispensable to German law, then the Constitutional Court might profitably transplant certain of the techniques employed by the US Supreme Court to preserve fundamental rights. For example, importation of strict scrutiny analysis would lend a degree of clarity and precision to German rights analysis. To a degree, this already has occurred, ${ }^{200}$ evidencing the transplantation of concepts across cultures, albeit with some adjustment. Perhaps pursuit of a mutual cultural influence is not so far off after all.

Acknowledgments Author would like to thank Professors Jay Conison of Oklahoma City and Bodo Pieroth of the University of Münster, Germany for their valuable comments on earlier drafts of this article. I would also like to thank Theresa Kruczek who helped prepare this article and Eric Schweibenz for his valuable research assistance. All translations are mine unless otherwise noted.

Open Access This article is distributed under the terms of the Creative Commons Attribution License which permits any use, distribution, and reproduction in any medium, provided the original author(s) and the source are credited.

\section{References}

Badura, P. 1964. Generalprävention und Würde des Menschen. Juristenzeitung 19: 337.

Brugger, W. 1994. Legal interpretation, schools of jurisprudence, and anthropology: Some remarks from a German point of view. American Journal of Comparative Law 41: 395.

Currie, P. 1994. The constitution of the Federal Republic of Germany. Chicago: University of Chicago Press.

Degenhart, C. 1992. Das allgemeine Persönlichkeitsrecht. Juristische Schulung 5: 361.

Dworkin, R. 1977. Taking rights seriously. Cambridge: Harvard University Press.

Dworkin, R. 1986. Law's empire. Cambridge: Harvard University Press.

Eberle, E.J. 1992. Practical reason: The commercial speech paradigm. Case Western Reserve Law Review 42: 411.

Eberle, E.J. 1999. Comparative public law: A time that has arrived. Festschrift for Bernhard Grossfeld. Heidelberg: Recht und Wirtschaft.

Ewald, W. 1995. Comparative Jurisprudence (I): What was it like to try a rat? University of Pennsylvania Law Review 143: 1889.

Fletcher, P. 1984. Human dignity as a constitutional value. University of Western Ontario Law Review 22: 171.

Hubmann, H. 1967. Das Persönlichkeitsrecht (2d ed. 1967). Köln: Böhlau Verlag.

Hofmann, H. 1993. Die versprochene Menschenwürde. Archiv des Öffentlichen Rechts 111: 353.

Kant, I. 1959. Foundations of the Metaphysics of Morals. L.W. Beck.

Kommers, DP. 1989. The Constitutional Jurisprudence of the Federal Republic of Germany. Duke University Press.

Krause, HD. 1965. The right to privacy in Germany-pointers for American Legislation. Duke Law Journal 481.

Maunz, T. 1993. Grundgesetz. Kommentar Nomos: Nomos.

Nozick, R. 1974. Anarchy, State and Utopia. New York: Basic Books.

Pieroth, B., and B. Schlink. 1994. Grundrechte Staatsrecht II, 10th ed. Heidelberg: CF Mueller Verlag.

$\overline{200}$ Right to Heritage II, 90 BVerfGE 263, 271 (1994). 
Quint, P.E. 1989. Free speech and private law in German constitutional theory. Modern Law Review 48: 247.

Rawls, J. 1971. A theory of justice. Cambridge: Harvard University Press.

Rawls, J. 1993.

Schwartz, P. 1989. The computer in German and American Constitutional law: Towards an American right of informational self-determination. American Journal of Comparative Law 37: 675.

von Mangoldt, H., F. Klein, and C. Starck. 1985. Das Bonner Grundgesetz, Article 2(1), § 64, 3rd ed. München: Vahlen.

von Muench, I. 1981. Grundesetz, Kommentar. 1: 72-73, 2nd ed. Nomos: Nomos. 